\title{
Fabrication and Evaluation of Ni-MLCC Used of New $\mathrm{BaTiO}_{3}$ Resinate
}

\author{
Ryosuke UEYAMA, Kiyoshi KURIBAYASHI* and Kunihito KOUMOTO** \\ Daiken Chemical Industry Corporation Limited, 2-7-19, Hanaten-nishi, Joto-ku, Osaka-shi 536-0011 \\ *Department of Environmental \& Material Engineering, Teikyo University of Science and Technology, \\ Yatsuzawa, Uenohara-machi, Kitatsuru-gun, Yamanashi 409-0193 \\ **Department of Applied Chemistry, Gradate School of Engineering, Nagoya University, Furou-cho, Chikusa-ku, Nagoya-shi 464-8603
}

\author{
$\mathrm{BaTiO}_{3}$ レジネートを用いた Ni-MLCC の作製評価 \\ 上山竜祐 $\cdot$ 栗林 清* $\cdot$ 河本邦仁** \\ 大研化学工業(株)製造技術部電極グループ，536-0011 大阪市城東区放出西 2-7-19 \\ *帝京科学大学理工学部環境マテリアル学科, 409-0193 山梨県北都留郡上野原町八つ沢 \\ **名古屋大学大学院工学研究科物質制御工学専攻, 464-8603 名古屋市千種区不老町
}

\begin{abstract}
In order to obtain thinner Ni electrode layers for $\mathrm{MLCCs}, \mathrm{BaTiO}_{3}$ organometal resinate was added into Ni paste, which consisted of $0.2 \mu \mathrm{m}$ or $0.4 \mu \mathrm{m}$ Ni powders. Ni electrode films were fabricated with the Ni paste added with $\mathrm{BaTiO}_{3}$ organometal resinate, and sintering and electrical characteristics of the film were examined in the present study. The experimental results indicated that addition of $\mathrm{BaTiO}_{3}$ organometal resinate as small as 1 mass $\%$ remarkably suppressed the sintering of the $\mathrm{Ni}$ electrode films, i.e., no abnormal grain growth was observed on $\mathrm{Ni}$ electrode films with $\mathrm{BaTiO}_{3}$ organometal resinate. In addition, MLCCs with 10-stacked layers was experimentally fabricated. The results indicate that the continuity of electrodes characteristics of the MLCCs are not impaired regardless of the size of the $\mathrm{Ni}$ particles. An addition of $\mathrm{BaTiO}_{3}$ organometal resinate was found to be extremely effective for obtaining thin electrode layers.

[Receiverd January 15, 2004; Accepted May 26, 2004]
\end{abstract}

Key-words : Ni-MLCC, Ni paste, $\mathrm{BaTiO}_{3}$ resinate

\section{Introduction}

The demand for multilayer ceramic chip capacitors (MLCCs) has been rapidly increasing, and smaller capacitors with larger capacitance have been introduced into the market. The capacitance is directly proportional to the dielectric constant and the number of dielectric layers, and inversely proportional to a thickness of dielectric layer. In order to achieve small-size capacitors with larger capacitance, it is required not only materials with larger dielectric constant, and a larger number of thinner dielectric layers, but also thinner electrode layers. From the viewpoint of fabrication of thinner electrode layers, we have studied on the synthesis of monodispersed Ni powder via pulverization of agglomerated particles and other methods. ${ }^{1)-4)}$

Recently, smaller particle size Ni powder has been required to realize thoroughly thinner electrode layers which are essential for production of smaller MLCCs. Our previous studies $^{5)-7)}$ revealed that sintering of $\mathrm{Ni}$ electrode films was remarkably suppressed for the electrode paste in which additives particles, generally $\mathrm{BaTiO}_{3}$ particles, were occupied between Ni particles and at triangle position (three pockets) of Ni particles. The three pockets of Ni particles are $0.054 \mu \mathrm{m}$ in size for Ni powder with $0.2 \mu \mathrm{m}$ in particle size. This is much smaller than currently used $\mathrm{BaTiO}_{3}$ additives which have approximately $0.1 \mu \mathrm{m}$ in particle size.

Therefore, we have used barium-titanate organometal resinate (BT resinate, hereafter) as an additive which has a similar composition to a dielectric green sheet. The experimental result ${ }^{8), 9)}$ clarified that the BT resinate showed a significant effect on suppression of sintering of $\mathrm{Ni}$ electrode films. In this study, an influence of the Ni particle size on the shrinkage suppression effect of the BT resinate was examined for $0.2 \mu \mathrm{m}$ and $0.4 \mu \mathrm{m}$ Ni powders. Furthermore, an MLCCs was fabricated and the continuity of electrodes of the MLCCs were evaluated in detail.

\section{Experimental methods}

2.1 Preparation and evaluation of electrode paste

Commercially available $\mathrm{Ni}$ powder synthesized by CVD method was used for the experiment. Figure 1 shows SEM images and a particle size distribution of the Ni powder. The $\mathrm{Ni}$ powder was pulverized to obtain monodispersed powder with $0.2 \mu \mathrm{m}$ and $0.4 \mu \mathrm{m}$ in average particle size. In the pulverization process, $\mathrm{n}$-hexane was used as a dispersion agent, and the flow velocity and flow length of Ni slurry were controlled by using a media mill during the wet pulverization. ${ }^{2}$ )

Approximately 1 mass $\%$ of the BT resinate was added as a sintering inhibitor into pulverized $\mathrm{Ni}$ powders. And ethylcellulose (binder) and terpineol (solvent) were added to the mixture. The resultant mixture was kneaded to paste with a conventional kneader. In order to characterize a sintering property of the paste, shrinkage of $\mathrm{Ni}$ electrode films after firing was measured via the following procedure. A film of approximately $200 \mu \mathrm{m}$ in thickness was formed on a polyethylene terephthalate (PET) film using an applicator and then dried for $1 \mathrm{~h}$ at $100^{\circ} \mathrm{C}$. The dried film was peeled from the PET film and was cut into $20 \mathrm{~mm}$ diameter disks with a punch. The disks were fired with temperature increasing speed $3^{\circ} \mathrm{C} / \mathrm{min}$ and maintained at temperatures ranging from 600 to $1300^{\circ} \mathrm{C}$ for $1 \mathrm{~h}$ in a reducing atmosphere consisted of $97 \% \mathrm{~N}_{2}$ $+3 \% \mathrm{H}_{2}$. Shrinkage of the disks after firing was measured. A surface microstructure of the electrode films fired at various temperatures was observed by using a scanning electron microscope (SEM, JSM-6100, Nippon Denshi).

\subsection{Fabrication of MLCCs}

A dielectric paste was prepared from dielectrics with X7R characteristics. MLCCs were obtained from the dielectric paste by the doctor blade method, i.e., Ni electrode was printed on the dielectric green sheet. These processes were repeated 10 times. A green sheet of the MLCCs with 10-stacked layers was fired under applied pressure and cut into $3.2 \times 1.6 \times 2.0$ 
(a)
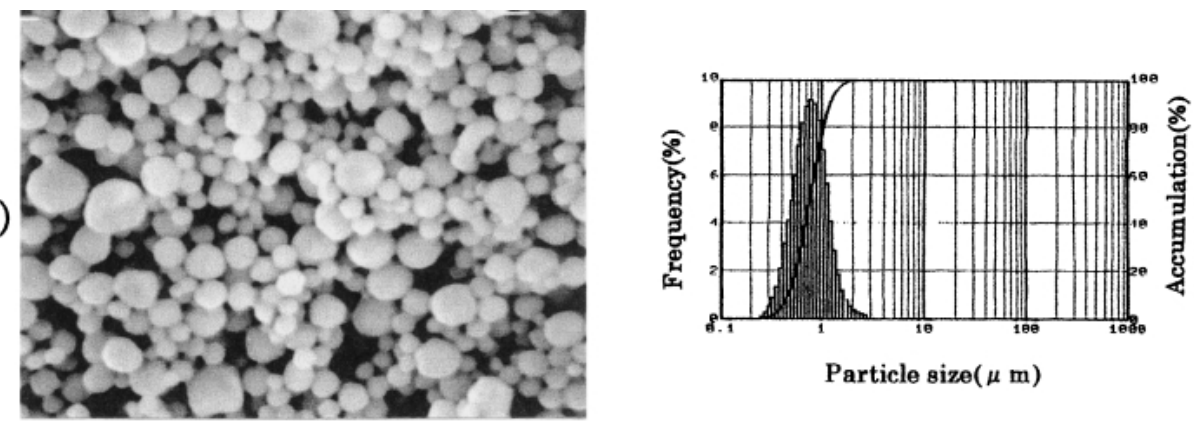

Particle size $(\mu \mathrm{m})$

(b)
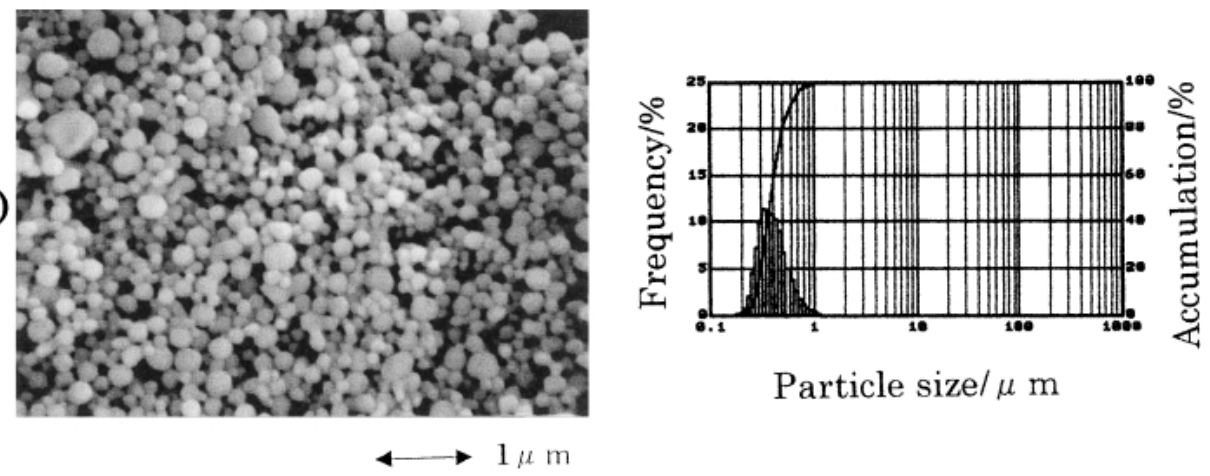

Particle size $/ \mu \mathrm{m}$

Fig. 1. SEM Photographs and particle size distribution of Ni powder prepared by CVD method. (a) $0.4 \mu \mathrm{m}$, (b) $0.2 \mu \mathrm{m}$.

$\mathrm{mm}^{3}$ (3216 type) in size.

The green MLCCs chips were degreased by heat treatment at $280^{\circ} \mathrm{C}$ for $8 \mathrm{~h}$ in air and then fired at $1315^{\circ} \mathrm{C}$ for $2 \mathrm{~h}$ in a strong reducing atmosphere (oxygen partial pressure $P_{\mathrm{O}_{2}}=$ $\left.10^{-13} \mathrm{MPa}\right)$. The MLCCs chips were thoroughly heat-treated at $1000^{\circ} \mathrm{C}$ for $3 \mathrm{~h}$ under the oxygen partial pressure $10^{-6}-10^{-7}$ $\mathrm{MPa}$ to re-oxidize the dielectrics in the MLCCs. The oxygen partial pressure was controlled with varying the $\mathrm{H}_{2}$ to $\mathrm{H}_{2} \mathrm{O}$ ratio in the $\mathrm{N}_{2}-\mathrm{H}_{2}-\mathrm{H}_{2} \mathrm{O}$ gas mixture.

2.3 Preparation of specimen for observation of microstructure and its evaluation

The MLCC was polished in the direction perpendicular to the electrode and dielectric layers so that the microstructures of both the electrode and dielectric could be simultaneously observed. The polished sample was observed by a metallurgical microscope to examine continuity of the electrode and other factors.

\section{Results and discussion}

3.1 Effect of addition of $\mathrm{BaTiO}_{3}$ resinate on firing shrinkage of $\mathrm{Ni}$ electrode films

Figure 2 shows the relationship between a firing temperature and shrinkage curve of electrode films consisted of $0.2 \mu \mathrm{m}$ and $0.4 \mu \mathrm{m} \mathrm{Ni}$ powder without an addition of $\mathrm{BaTiO}_{3}$ and with the BT resinate fired at temperatures ranging from 600 to $1300^{\circ} \mathrm{C}$, respectively. A shrinkage curve of the generally used dielectric green sheet is also plotted by a mark " $\times$ " in Fig. 2, because the aim of the present study is to obtain Ni electrode films with similar shrinkage to that of the dielectric green sheet. As is obvious from the figure, shrinkage of $\mathrm{BaTiO}_{3}$-free $\mathrm{Ni}$ electrode film is large. This is because the sintering generally proceeds more easily as decrease in particle size. Green density of the electrode film decreases as decrease in Ni parti-

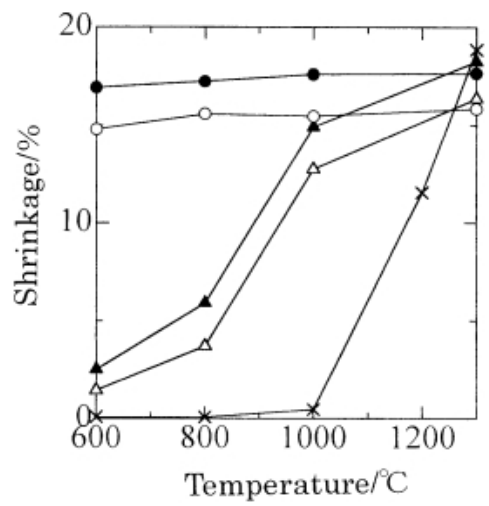

Fig. 2. Relationships between firing temperature and shrinkage of $\mathrm{Ni}$ electrode films. $\mathrm{O}$ : prepared from $0.2 \mu \mathrm{m}$ Ni powder with no $\mathrm{BaTiO}_{3}$ resinate, $\mathbf{\Delta}$ : prepared from $0.2 \mu \mathrm{m} \mathrm{Ni}$ powder with addition of $\mathrm{BaTiO}_{3}$ resinate, $\bigcirc$ : prepared from $0.4 \mu \mathrm{m}$ Ni powder with no $\mathrm{BaTiO}_{3}$ resinate, $\triangle$ : prepared from $0.4 \mu \mathrm{m}$ Ni powder with addition of $\mathrm{BaTiO}_{3}$ resinate, $\times$ : dielectric green sheet.

cle size as shown in Fig. 3. A thickness of the resin covered $\mathrm{Ni}$ particles, which causes a decrease of the packing density of the electrode films as clarified in our previous study, ${ }^{3)}$ directly influences on the shrinkage of the electrode films. Since a percentage of the resin covered $\mathrm{Ni}$ particles increases as decrease in particle size of $\mathrm{Ni}$, the shrinkage of electrode films may increase because of burn away of the resin.

On the other hand, the shrinkage of the Ni electrode with addition of BT resinate is close to that of the dielectric green sheet. It is indicating that the shrinkage of the electrode films was fairly suppressed by an addition of the BT resinate. It was 
clarified that an addition of the BT resinate is extremely effective for the Ni paste used for an even thinner electrode layer. However, the shrinkage of the Ni films with the BT resinate did not completely correspond to that of the dielectric green sheet. Further investigations on the amount of addition of the BT resinate should be performed in the future.

3.2 Effect of addition of BT resinate on microstructure of the sintered electrode surface

In order to confirm the effect of an addition of the BT resinate, the change in the microstructure of the surface of the sintered Ni films with $0.2 \mu \mathrm{m}$ and $0.4 \mu \mathrm{m}$ in particle size was examined. Figures 4 and $\mathbf{5}$ show SEM images of a surface of the sintered Ni films (a) without an addition and (b) with an addition of the BT resinate, respectively. As observed from the microstructures in Figs. 4(a) and 5(a), a particle growth

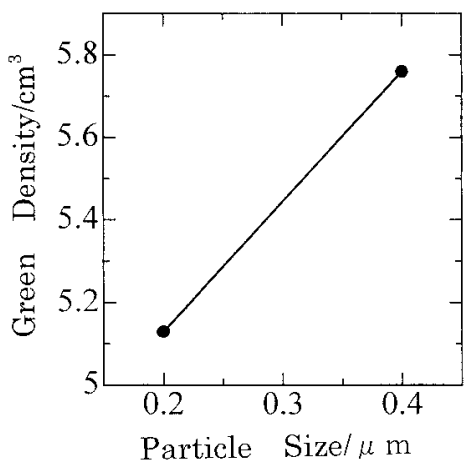

Fig. 3. Relationships between green density of Ni electrode films and particle size of Ni powder. started approximately at $600^{\circ} \mathrm{C}$ and marked at $800^{\circ} \mathrm{C}$. The particles growth was observed significantly at $1000^{\circ} \mathrm{C}$ or the higher. In the other words, a sintering proceeds at lower temperatures as decrease in particle size. Therefore, it is impossible for the currently adopted firing process of MLCCs to use Ni paste without an addition of the BT resinate.

Consequently, in order to apply $\mathrm{Ni}$ electrode paste for the currently adopted MLCCs firing process, the BT resinate was added to the Ni paste. The change in the microstructure of the fired $\mathrm{Ni}$ films is shown in Figs. 4(b) and 5(b). No neck growth of Ni particles was observed at $600^{\circ} \mathrm{C}$ for the Ni pastes prepared from $0.2 \mu \mathrm{m}$ and $0.4 \mu \mathrm{m}$ Ni powders. Growth of $\mathrm{Ni}$ particles was observed at $800^{\circ} \mathrm{C}$. Abnormal particle growth, which was observed for the Ni paste without an addition of the $\mathrm{BT}$ resinate, was not observed. For the films fired at $1000^{\circ} \mathrm{C}$, a size of the grown particles was approximately half of that for Ni paste without the BT resinate. A particle size of the films with the BT resinate sintered at $1300^{\circ} \mathrm{C}$ was similar to that for the $\mathrm{Ni}$ paste without the $\mathrm{BT}$ resinate sintered at $1000^{\circ} \mathrm{C}$. It is considered that an addition of the $\mathrm{BT}$ resinate suppresses the sintering of Ni electrode films since the BT resinate occupied at the grain boundaries and at three pockets of the Ni particles. However, the mechanism associated with this suppression of sintering has not been clarified yet, and will be examined in the future.

3.3 MLCCs prepared continuity of $\mathrm{Ni}$ electrodes with BT resinate and an observation of a microstructure

A metallograph microscope observation was carried out on the cross section of MLCCs in which $\mathrm{Ni}$ electrode layers include as little as 1 mass $\%$ of the BT resinate. Figures 6 (a) and (b) show the photographs of the observation. No electrode breaking was observed in the MLCCs, showing good
(1) $600^{\circ} \mathrm{C}$

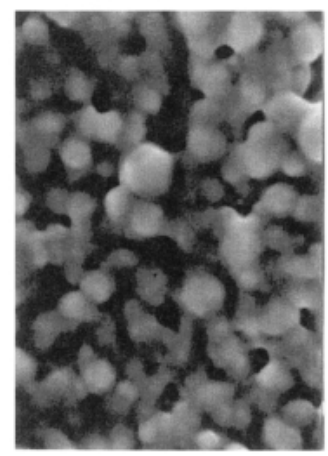

(b)

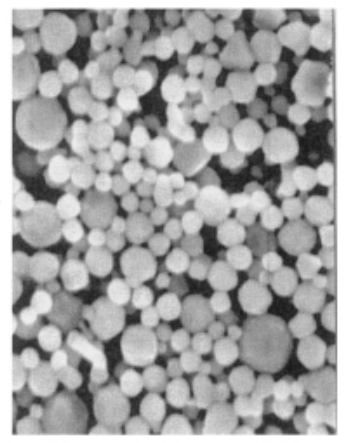

(2) $800^{\circ} \mathrm{C}$
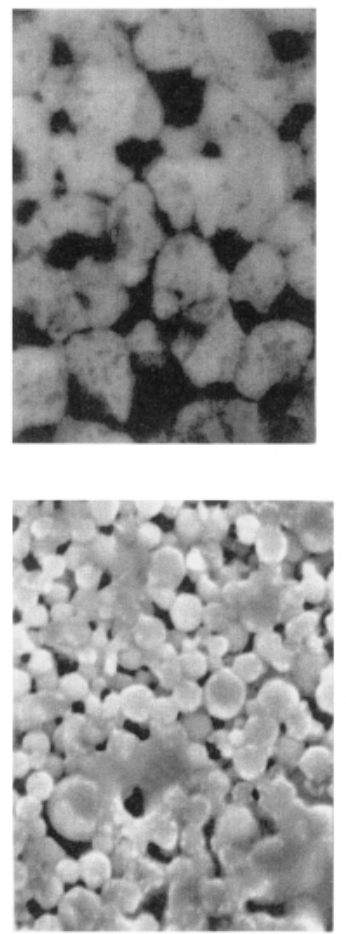

(3) $1000^{\circ} \mathrm{C}$
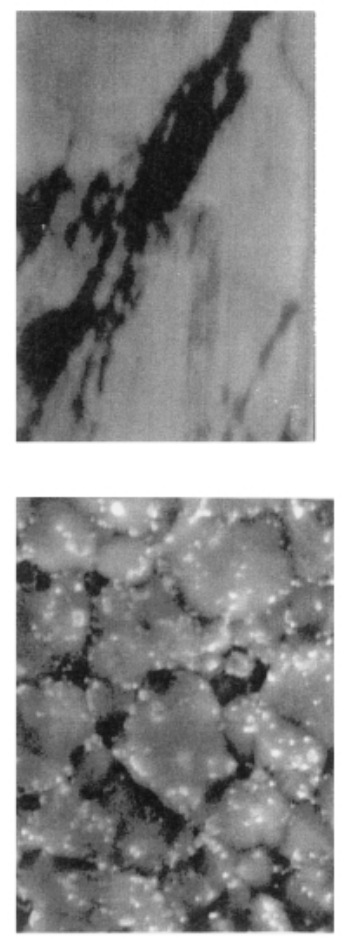

(4) $1300^{\circ} \mathrm{C}$
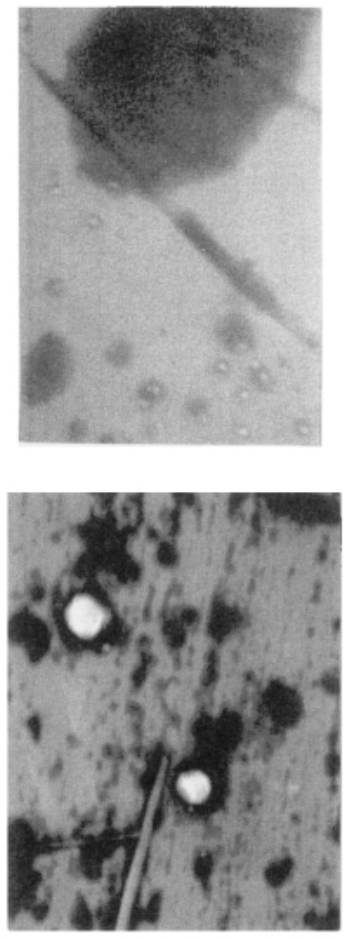

$\longleftrightarrow 1 \mu \mathrm{m}$

Fig. 4. SEM photographs of sintered Ni electrode films prepared from $0.4 \mu \mathrm{m}$ particle at various temperatures. (a) No addition of BT resinete, (b) with an addition of $\mathrm{BT}$ resinate. 
(1) $600^{\circ} \mathrm{C}$

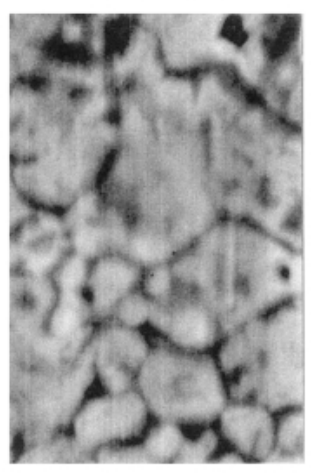

(b)

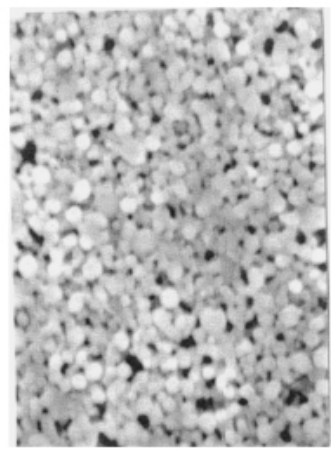

(2) $800^{\circ} \mathrm{C}$
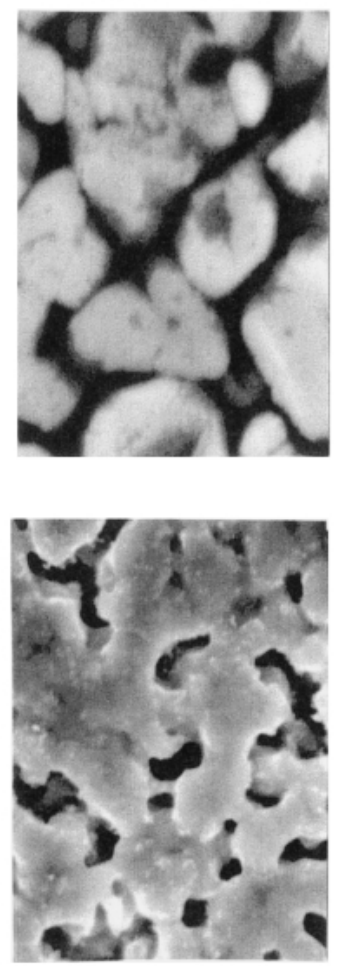

(3) $1000^{\circ} \mathrm{C}$
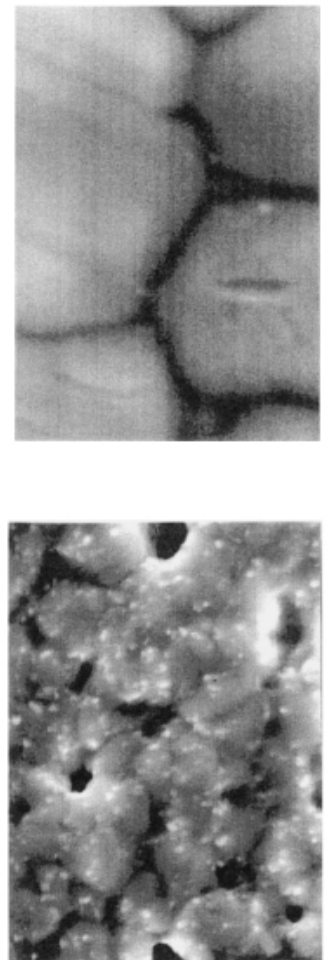

(4) $1300^{\circ} \mathrm{C}$
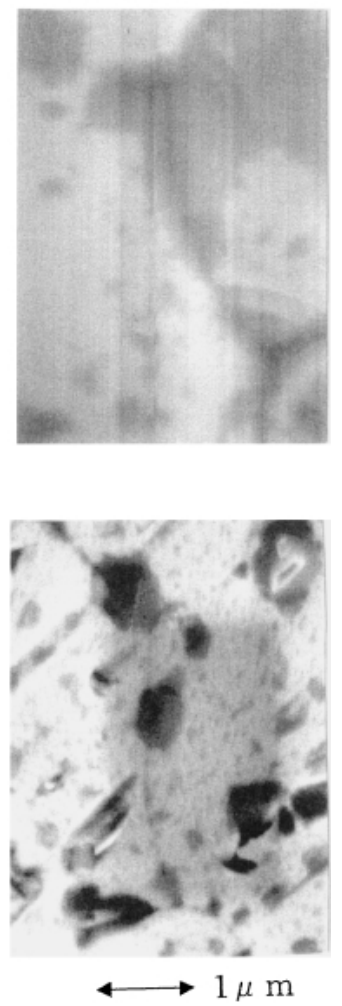

Fig. 5. SEM photographs of sintered Ni electrode film prepared from $0.2 \mu \mathrm{m}$ particle at various temperatures. (a) No addition of BT resinete, (b) with an addition of BT resinate.

(a)

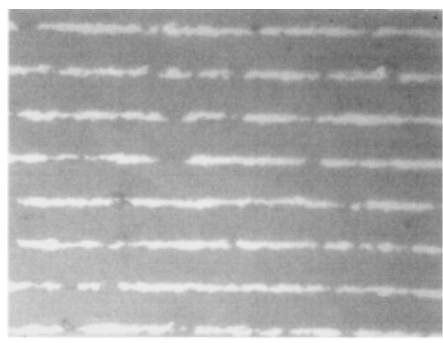

(b)

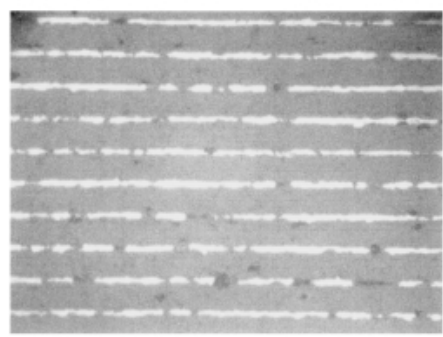

$\leftrightarrow 10 \mu \mathrm{m}$

Fig. 6. Cross-sectional views of MLCCs observed by metallographic microscope.

(a) Fabricated with $0.4 \mu \mathrm{m}$ Ni powder and BT resinate, (b) fabricated with $0.2 \mu \mathrm{m}$ Ni powder and BT resinate.

continuity of electrodes.

\section{Summary}

Aiming at obtaining a thinner electrode layers, the in- fluences of an addition of the BT resinate to $0.2 \mu \mathrm{m}$ and 0.4 $\mu \mathrm{m}$ Ni powders on the sintering suppression effect and electrical characteristics of the MLCC were examined. We obtained the following conclusions.

(1) An addition of the BT resinate to Ni paste showed a significant influence on the sintering suppression effect of the $\mathrm{Ni}$ electrode films in MLCCs.

(2) $\mathrm{Ni}$ electrodes with an addition of 1 mass $\% \mathrm{BT}$ resinate in MLCCs were fabricated with good continuity, i.e., no electrode breaking was observed.

\section{References}

1) Ueyama, R., Seki, N., Kamada, K., Harada, M. and Ueyama, T., J. Ceram. Soc. Japan, Vol. 107, pp. 652-656 (1999) [in Japanese].

2) Ueyama, R., Seki, N., Ueyama, T., Koumoto, K. and Kuribayashi, K., J. Ceram. Soc. Japan, Vol. 108, pp. 661-665 (2000) [in Japanese].

3) Ueyama, R., Ueyama, T. and Koumoto, K., J. Ceram. Soc. Japan, Vol. 108, pp. 769-773 (2000) [in Japanese].

4) Ueyama, R., Ueyama, T., Koumoto, K. and Kuribayashi, K., J. Ceram. Soc. Japan, Vol. 109, pp. 661-666 (2001).

5) Ueyama, R., Ueyama, T., Koumoto, K. and Kuribayashi, K., J. Ceram. Soc. Japan, Vol. 109, pp. 351-354 (2001) [in Japanese].

6) Ueyama, R., Ueyama, T., Koumoto, K., Kuribayashi, K. and Yamamoto, T., J. Jpn. Soc. Powder and Powder Metall., Vol. 48, pp. 392-396 (2001).

7) Ueyama, R., Ueyama, T., Koumoto, K. and Kuribayashi, K., Trans. Mater. Res. Soc. Japan, Vol. 27, pp. 13-17 (2002).

8) Ueyama, R., Koumoto, K. and Kuribayashi, K., J. Ceram. Soc. Japan, Vol. 110, pp. 870-873 (2002) [in Japanese].

9) Ueyama, R., Ueyama, T. and Koumoto, K., J. Ceram. Soc. Japan, Vol. 110, pp. 329-332 (2002) [in Japanese]. 